\title{
Influences of sand cover on erosion processes of loess slopes based on rainfall simulation experiments
}

\author{
ZHANG Xiang ${ }^{1,2,3}$, LI Zhanbin ${ }^{2,3}$, LI Peng ${ }^{3 *}$, TANG Shanshan ${ }^{3}$, WANG Tian ${ }^{3}$, ZHANG Hui ${ }^{3}$ \\ ${ }^{1}$ Post-doctoral Research Station of Xi'an Chan-Ba National Ecological District, Xi'an 710024, China; \\ ${ }^{2}$ State Key Laboratory of Soil Erosion and Dryland Farming on the Loess Plateau, Institute of Soil and Water Conservation, \\ Chinese Academy of Science and Ministry of Water Resources, Yangling 712100, China; \\ ${ }^{3}$ State Key Laboratory Base of Eco-Hydraulic Engineering in Arid Area, Xi'an University of Technology, Xi'an 710048, China
}

\begin{abstract}
Aeolian-fluvial interplay erosion regions are subject to intense soil erosion and are of particular concern in loess areas of northwestern China. Understanding the composition, distribution, and transport processes of eroded sediments in these regions is of considerable scientific significance for controlling soil erosion. In this study, based on laboratory rainfall simulation experiments, we analyzed rainfall-induced erosion processes on sand-covered loess slopes (SS) with different sand cover patterns (including length and thickness) and uncovered loess slopes (LS) to investigate the influences of sand cover on erosion processes of loess slopes in case regions of aeolian-fluvial erosion. The grain-size curves of eroded sediments were fitted using the Weibull function. Compositions of eroded sediments under different sand cover patterns and rainfall intensities were analyzed to explore sediment transport modes of SS. The influences of sand cover amount and pattern on erosion processes of loess slopes were also discussed. The results show that sand cover on loess slopes influences the proportion of loess erosion and that the compositions of eroded sediments vary between SS and LS. Sand cover on loess slopes transforms silt erosion into sand erosion by reducing splash erosion and changing the rainfall-induced erosion processes. The percentage of eroded sand from SS in the early stage of runoff and sediment generation is always higher than that in the late stage. Sand cover on loess slopes aggravates loess erosion, not only by adding sand as additional eroded sediments but also by increasing the amount of eroded loess, compared with the loess slopes without sand cover. The influence of sand cover pattern on runoff yield and the amount of eroded sediments is larger than that of sand cover amount. Furthermore, given the same sand cover pattern, a thicker sand cover could increase sand erosion while a thinner sand cover could aggravate loess erosion. This difference explains the existence of intense erosion on slopes that are thinly covered with sand in regions where aeolian erosion and fluvial erosion interact.
\end{abstract}

Keywords: aeolian-fluvial erosion; sand-covered loess slopes; sand cover amount; sand cover pattern; rainfall intensity; grain-size distribution; Inner Mongolia Reach of the Yellow River

Citation: ZHANG Xiang, LI Zhanbin, LI Peng, TANG Shanshan, WANG Tian, ZHANG Hui. 2018. Influences of sand cover on erosion processes of loess slopes based on rainfall simulation experiments. Journal of Arid Land, 10(1): 39-52. https://doi.org/10.1007/s40333-017-0074-7

\section{Introduction}

Erosion is an important factor that influences environmental quality and ecological stability. Co-erosion is a complex mechanism caused by various types of erosion, such as aeolian erosion

\footnotetext{
${ }^{*}$ Corresponding author: LI Peng (E-mail: lipeng74@163.com)

Received 2017-03-12; revised 2017-09-18; accepted 2017-10-19

(C) Xinjiang Institute of Ecology and Geography, Chinese Academy of Sciences, Science Press and Springer-Verlag GmbH Germany, part of Springer Nature 2018
} 
and fluvial erosion (Ta et al., 2014; Liu et al., 2016). One typical area containing these two erosion types (i.e., aeolian erosion and fluvial erosion) is the ten small tributaries to the Inner Mongolia Reach of the Yellow River where the Hobq Deserts is located (Li et al., 2015). This area is severely subjected to aeolian erosion and fluvial erosion (occurring alternately throughout the year), and it is the main source of coarse sediments in the Yellow River (Xu, 2014). In the ten small tributaries to the Inner Mongolia Reach of the Yellow River, the yield of eroded sediments and the length of erosion time are both increased by the superimposed effect of erosive power and erosion time, resulting in greater environmental and ecological influences. During the fluvial erosion period, the short-duration, high-intensity erosion prevails, and dryland fluvial systems often lead to intense soil erosion and sedimentation (Kocurek, 1998; Banham and Mountney, 2014). Therefore, understanding the mechanisms of aeolian erosion and fluvial erosion is of great importance to control and prevent the loss of soils.

In the ten small tributaries to the Inner Mongolia Reach of the Yellow River, the sand-covered loess slopes (SS) are widely distributed in the upstream areas (Zhang et al., 2015). The thickness of sand layer is $\sim 1.5 \mathrm{~cm}$ on average, and the maximum slope gradient of the SS is confirmed as $\sim 12^{\circ}$ in gully heads from both field investigations and ArcGIS analysis using a $90-\mathrm{m}$ resolution digital elevation model. Zhang et al. (2015) found that the upstream watershed section is the main source of eroded sediments and that the erosion dynamics are controlled by the fluvial processes. In later work, Yao et al. (2016) pointed out that the transported sediments in the Xiliugou Basin of the upper Yellow River (i.e., a region where aeolian erosion and fluvial erosion interact) is generated from the SS; they, therefore, concluded that SS are a key source of eroded sediments. This means that research on SS is important to understand the mechanisms of aeolian-fluvial erosion processes in the ten small tributaries to the Inner Mongolia Reach of the Yellow River.

Laboratory rainfall simulation experiments are one crucial approach for the study of the mechanisms of erosion on slopes. As previous studies have shown, during short-duration rainfall events, the rainfall intensity has a strong influence on runoff and sediment generation on slopes (Huang et al., 2016). Moreover, variations in the underlying surface conditions, such as plant cover (Garcia-Estringana et al., 2010), and sand, stone or gravel cover (Abrahams et al., 2001; Mandal et al., 2005; Turowski et al., 2010; Zhang et al., 2015), can also influence runoff generation and total eroded sediments by changing soil erosion processes (Wang and Shi, 2015). Compared with uncovered slopes, gravel cover on slopes can alter the characteristics of eroded sediments (Turowski et al., 2010). Stones resting on the soil surface can cause a pronounced reduction of runoff and sediment erosion and an increase of infiltration compared with those buried in the surface layer (Sun et al., 2002; Mandal et al., 2005). The sand-covered slopes can generate higher amount of eroded sediments and greater median grain size of eroded sediments than the uncovered slopes (Xu et al., 2015). To date, few studies have systematically examined the erosion processes of SS at different rainfall intensities in aeolian-fluvial erosion regions.

The objective of this research was to investigate the influences of sand cover on erosion processes of loess slopes using rainfall simulation experiments. The composition, distribution, and transport processes of eroded sediments from SS and uncovered loess slopes (LS) were explored. Specifically, we fitted the grain-size curves of eroded sediments, and obtained the composition and source of eroded sediments from SS and LS based on grain-size distribution curves. We also described the variability characteristics of eroded sediments during runoff and sediment generation, and analyzed the influences of rainfall intensity, sand cover amount, and sand cover pattern on erosion processes. It is our hope that this research will help to elucidate the influences of sand cover on erosion processes of loess slopes and to provide a rationale for further in-depth studies of the co-erosion processes in the aeolian-fluvial interplay erosion regions.

\section{Materials and methods}

\subsection{Study area}

The loess samples used in the rainfall simulation experiments were collected from the upper 
watershed of Dongliu Gully, which is one of the ten small tributaries to the Inner Mongolia Reach of the Yellow River. The aeolian sand samples were collected from the Hobq Deserts, which is crossing the middle watershed of the Dongliu Gully. The Dongliu Gully watershed has a typical continental climate, with long, cold winters and short, hot summers. Runoff is primarily recharged by floods following heavy rain, with rainfall occurring mainly in the form of storms. Fluvial erosion in the study area is dominated by rainstorm-induced floods. Grain-size characteristics of the loess and sand in the study area are shown in Table 1.

Table 1 Grain-size characteristics of the experimental loess and sand

\begin{tabular}{ccccc}
\hline Type & $\mathrm{d}_{50}(\mathrm{~mm})$ & Clay $(\%)$ & Silt $(\%)$ & Sand $(\%)$ \\
\hline Loess & 0.010 & 13.20 & 82.53 & 4.27 \\
Sand & 0.418 & 0.09 & 3.30 & 96.61 \\
\hline
\end{tabular}

Note: $\mathrm{d}_{50}$ is the medium value of the grain-size distribution.

\subsection{Experimental design and set-up}

Before the rainfall simulation experiments, 9 loess samples and 9 sand samples were collected for the analyses of the basic sediment grain size. Grain-size analysis of the loess and sand samples was conducted using a Malvern Mastersizer 2000 laser grain-size analyzer (Malvern, UK). The sediment grain-size curves of these samples were averaged and taken as the background grain-size curves.

All collected loess and sand samples used to rainfall simulation experiments were sieved with a $10-\mathrm{mm}$ sieve before they were packed into the soil bin. Rainfall simulation experiments were conducted at the water and soil erosion laboratory of Xi'an University of Technology during July-September in 2013. We used a slope test apparatus to perform laboratory simulation experiments. The experimental soil bin comprised a mobile steel container with $13.0 \mathrm{~m} \times 1.0$ $\mathrm{m} \times 0.6 \mathrm{~m}$ dimensions. The experimental slope gradient was set at $12^{\circ}$. The reasons are as follows. First, it has been proven that the maximum slope gradient of the SS is $\sim 12^{\circ}$ in the gully head of the ten small tributaries to the Inner Mongolia Reach of the Yellow River (Zhang et al., 2015). Second, Foster et al. (1984) concluded that the critical slope gradient of erosion is less than $25^{\circ}$. Third, Zheng et al. (2005) and Shen et al. (2016) found that the erosion characteristics at slope gradients of $3^{\circ}-12^{\circ}$ are different from those at slope gradients of $12^{\circ}-25^{\circ}$. We therefore considered $12^{\circ}$ to be the critical slope gradient in this study and used it as our experimental slope gradient.

The schematic diagram and stereogram of the simulated rainfall system used in this study are shown in Figure 1. Specifically, the lowermost layer of the soil bin was filled with 0.1-m-thick coarse gravel wrapped in gauze to ensure water permeability, and a 0.2-m-thick coarse gravel was laid at the bottom of the bin to keep the soil drainage conditions of the test close to those of a natural slope. The middle layer of the soil bin comprised a $0.25-\mathrm{m}$-thick experimental loess soil samples, with mean bulk density of $1.3 \mathrm{~g} / \mathrm{cm}^{3}$ and water content of $20 \%$. The uppermost layer of the soil bin encompassed sand cover with different patterns (including thickness and length). The uppermost layer of the soil bin without sand cover (i.e., LS) was considered as control. According to the results of Ta et al. (2014), we designed three sand cover thicknesses $(0.5,1.0$, and $1.5 \mathrm{~cm})$ that are relatively common in aeolian-fluvial erosion regions. The total length of loess slope is $13.0 \mathrm{~m}$. The lengths of sand cover on loess slopes were designed as 13.0, 9.9, 6.6, and $3.3 \mathrm{~m}$, corresponding to the whole slope, about three-quarters of slope, about one-half slope, and about a quarter of slope, respectively. It should be noted that if the sand cover length in any experimental test was less than $13.0 \mathrm{~m}$, then this length was calculated upwards from the bottom of the soil bin. Once the sand cover was established within the test apparatus, two points were chosen randomly within each meter to ensure that the sand layer thickness was constant. Therefore, a total of 26 randomly chosen points were selected for this study.

A side sprinkler device was used to simulate rainfall from an effective height of $4 \mathrm{~m}$. We applied three levels of rainfall intensity $(1.0,1.5$, and $2.0 \mathrm{~mm} / \mathrm{min}$ ) based on the rainfall characteristics of the study area. For rainfall intensity levels of 1.0 and $1.5 \mathrm{~mm} / \mathrm{min}$, the rainfall 
duration was set to $30 \mathrm{~min}$; while for rainfall intensity level of $2 \mathrm{~mm} / \mathrm{min}$, the rainfall duration was set to $15 \mathrm{~min}$ because of a water feeding issue. Finally, a total of 11 experimental tests were performed (Table 2), with three replicates for each. The results presented in the following are the average of the three replicates.
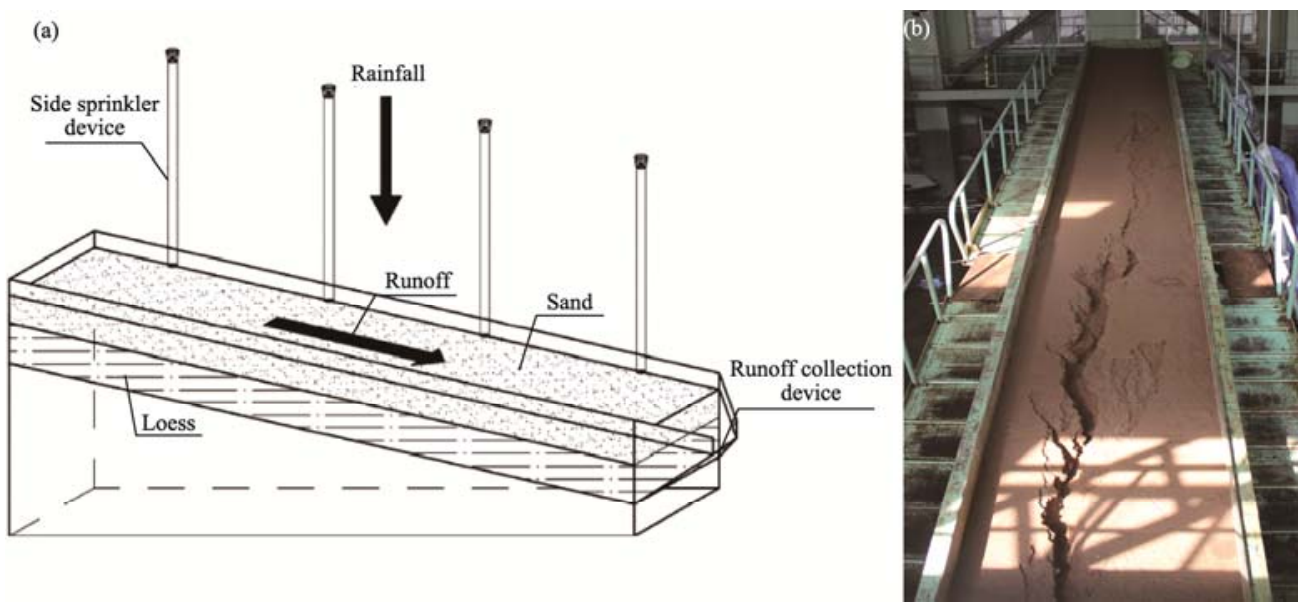

Fig. 1 (a) Schematic diagram and (b) stereogram of the simulated rainfall system

Table 2 Design of experimental tests for the rainfall simulation experiments

\begin{tabular}{cccc}
\hline Test No. & Sand cover length $(\mathrm{m})$ & Sand cover thickness $(\mathrm{cm})$ & Rainfall intensity $(\mathrm{mm} / \mathrm{min})$ \\
\hline LS-1.5 & 0.0 & 0.0 & 1.5 \\
LS-1.0 & 0.0 & 0.0 & 1.0 \\
LS-2.0 & 0.0 & 0.0 & 2.0 \\
SS-13.0-1.0-2.0 & 13.0 & 1.0 & 2.0 \\
SS-13.0-1.0-1.5 & 13.0 & 1.0 & 1.5 \\
SS-13.0-1.0-1.0 & 13.0 & 1.0 & 1.0 \\
SS-13.0-0.5-1.5 & 13.0 & 0.5 & 1.5 \\
SS-13.0-1.5-1.5 & 13.0 & 1.5 & 1.5 \\
SS-3.3-1.0-1.5 & 3.3 & 1.0 & 1.5 \\
SS-9.9-1.0-1.5 & 9.9 & 1.0 & 1.5 \\
SS-6.6-1.0-1.5 & 6.6 & 1.0 & 1.5 \\
\hline
\end{tabular}

Note: LS, uncovered loess slopes; SS, sand-covered loess slopes. The test number was expressed as loess slope type-sand cover length (m)-sand cover thickness $(\mathrm{cm})$-rainfall intensity $(\mathrm{mm} / \mathrm{min})$.

\subsection{Experimental process and data analysis}

The water was sprinkled evenly across the slopes to ensure that water infiltration was closer to the natural soil water distribution, then the simulated slopes were allowed to stand for $24 \mathrm{~h}$ before the simulated rainfall events. The water content in the soil was controlled at $20 \%$. Before the experiments, rainfall intensity was calibrated to test its uniformity. During the experiments, the amount of runoff and eroded sediments per minute was sampled using a pycnometer to calculate the sediment concentration. The remaining runoff and eroded sediments were collected using a bucket. The water and eroded sediments in the pycnometer were added to the bucket after the calculation of sediment concentration. Finally, the water and sediments in the bucket were weighed to calculate the amount of water and of eroded sediments produced in $1 \mathrm{~min}$. The amount of eroded sediments per minute in the runoff was measured using an oven-drying method. All eroded sediments were precipitated and placed in mess tins in a drying oven at $105^{\circ} \mathrm{C}$ for $8 \mathrm{~h} \mathrm{(Shi}$ et al., 2012). On both sides of the soil bin, 0.5-m-high splash erosion plates were set upright to collect the splash-eroded sediments. All samples were sieved with a 2-mm sieve. Then a Malvern Mastersizer 2000 laser grain-size analyzer (Malvern Instruments, Ltd., UK) was used to 
determine the grain size of eroded sediments.

Grain characteristics, including size and distribution, are related to transport media, transport modes, and dynamic erosion conditions. The combination of eroded sediments from multiple sources leads to variations in the number and position of peaks in the grain-size distribution curve, and therefore, variations in the curve can reflect the changes in sediment composition (Weltje and Prins, 2007). If a grain-size distribution curve follows a polymodal distribution, then it can be concluded that the distribution is made up of multiple, superposed standard unimodal functions. In other words, the polymodal grain-size distributions of loess and sand sediments are resulted from multiple single-fraction.

Three distribution functions are fitted to the sediment grain-size distribution: normal (Sun et al., 2001), lognormal (Xiao et al., 2013), and Weibull (Sun et al., 2002; Zhang et al., 2015). However, as the normal function has a zero skewness coefficient, it is not a suitable fit for the variety of grain-size distribution (Sun et al., 2001). Sun et al. (2002) noted that the Weibull function fits better than its lognormal counterpart in the case of aeolian and hydraulic sediments; Zhang et al. (2015) also showed that the Weibull function encompasses an appropriate distribution when characterizing sediment from aeolian and fluvial erosion, providing satisfactory results for sand-loess mixtures. Therefore, we selected the Weibull function to describe the sediment grain-size distribution in this study. The equation of the Weibull function is as follows (Sun et al., 2002; Zhang et al., 2015):

$$
\begin{gathered}
f(x ; \lambda, k)=\frac{k}{\lambda}\left(\frac{x}{\lambda}\right)^{k-1} \mathrm{e}^{-(x / \lambda)^{k}}(\text { if } x \geq 0), \\
f(x ; \lambda, k)=0 \text { (if } x<0),
\end{gathered}
$$

where $x$ is a random variable that represents the grain-size fraction of the sediment; $\lambda$ is a scale parameter; and $k$ is a shape parameter. Each unimodal component can be described with sufficient accuracy by the Weibull function, and the distributions of polymodal sediments that consist of several unimodal fractions are considered to be a mixed grain-size distribution of the unimodal fractions. Assuming that the distribution function $f(x ; \lambda, k)$ of polymodal sediments has four possible sources, i.e., $f_{1}\left(x_{1} ; \lambda_{1}, k_{1}\right), f_{2}\left(x_{2} ; \lambda_{2}, k_{2}\right), f_{3}\left(x_{3} ; \lambda_{3}, k_{3}\right)$ and $f_{4}\left(x_{4} ; \lambda_{4}, k_{4}\right)$, then the following relationship is satisfied:

$$
\begin{aligned}
& f(x ; \lambda, k)=a f_{1}\left(x_{1} ; \lambda_{1}, k_{1}\right)+b f_{2}\left(x_{2} ; \lambda_{2}, k_{2}\right)+c f_{3}\left(x_{3} ; \lambda_{3}, k_{3}\right)+d f_{4}\left(x_{4} ; \lambda_{4}, k_{4}\right) . \\
& a+b+c+d=1
\end{aligned}
$$

The Weibull distribution parameters of the unimodal fractions were first estimated by minimizing the residual differences between the measured and fitted grain-size curve of the basic sediment samples. The percentage parameters, i.e., $a, b, c$ and $d$, for the polymodal sediments were then determined by minimizing the residual differences between the measured and fitted grain-size curve of the eroded sediments from LS and SS. The calculation is conducted by R compiler.

\section{Results}

\subsection{Basic characteristics of sediment grain size}

As shown in Figure 2, the basic grain-size distribution curves of the loess and sand used in the rainfall simulation experiments exhibited different bimodal distributions. Using the two grain-size curves of the basic loess and sand samples as objective functions, we applied two Weibull functions for fitting without constraints, with the minimum fitting residuals as the fitting results of the two functions. In this case, $\mathrm{C} 1$ refers to the fine loess grains (accounting for $36.2 \%$ of the loess grain), which are mainly composed of clay and have a $\mathrm{d}_{50}$ of $0.003 \mathrm{~mm}$. Similarly, C2 refers to the coarse loess grains (accounting for $63.8 \%$ of the loess grain), which are mainly composed of fine silt particles and have a $\mathrm{d}_{50}$ of $0.016 \mathrm{~mm}$. C3 refers to the fine sand grains (accounting for $2.8 \%$ of the sand grain), which are mainly composed of coarse silt particles and have a $\mathrm{d}_{50}$ of $0.041 \mathrm{~mm}$. Finally, C4 refers to the coarse sand grains (accounting for $97.2 \%$ of the sand grain), which are mainly composed of medium sand particles and have a $\mathrm{d}_{50}$ of $0.373 \mathrm{~mm}$. 

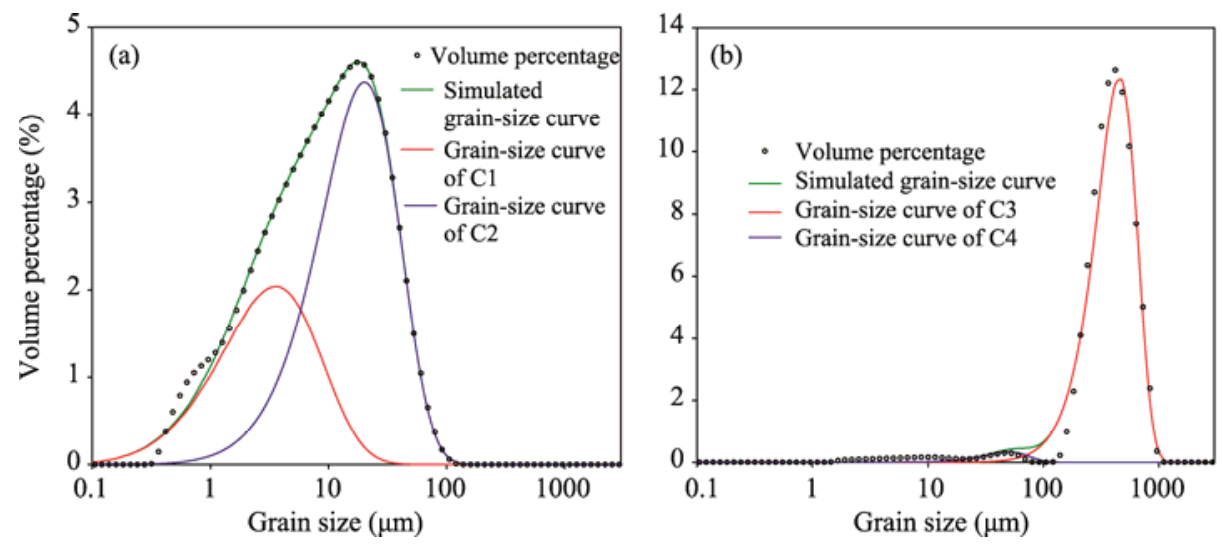

Fig. 2 Model fitting results for the basic grain-size distributions of loess (a) and sand (b) used in the rainfall simulation experiments. $\mathrm{C} 1$, the fine loess grains; $\mathrm{C} 2$, the coarse loess grains; $\mathrm{C} 3$, the fine sand grains; $\mathrm{C} 4$, the coarse sand grains.

The grain-size characteristics of the four fractions (C1, C2, C3 and C4) are shown in Table 3. The $\mathrm{d}_{50}$ values of the four fractions increased in turn. The sorting coefficients were different between loess ( $\mathrm{C} 1$ and $\mathrm{C} 2$ ) and sand (C3 and $\mathrm{C} 4)$, with the sorting behavior of sand being better than that of loess. All four distribution curves showed positive skewness, and their kurtoses were moderate with little differences. To sum up, the $\mathrm{d}_{50}$, kurtosis, skewness, and sorting coefficient values varied with the fraction $(\mathrm{C} 1-\mathrm{C} 4)$, reflecting that their differences were quite large and the large differences were the preconditions for the gradation curve (grain-size distribution) analyses.

Table 3 Grain-size characteristics of the four fractions

\begin{tabular}{ccccc}
\hline Fraction & $\mathrm{d}_{50}(\mathrm{~mm})$ & Sorting coefficient & Skewness & Kurtosis \\
\hline $\mathrm{C} 1$ & 0.003 & 3.83 & 0.70 & 1.00 \\
$\mathrm{C} 2$ & 0.016 & 3.07 & 0.10 & 1.02 \\
$\mathrm{C} 3$ & 0.041 & 1.92 & 0.12 & 1.04 \\
$\mathrm{C} 4$ & 0.373 & 1.85 & 0.13 & 1.04 \\
\hline
\end{tabular}

Note: $\mathrm{C} 1$, the fine loess grains; $\mathrm{C} 2$, the coarse loess grains; $\mathrm{C} 3$, the fine sand grains; $\mathrm{C} 4$, the coarse sand grains.

\subsection{Composition of eroded sediments from SS and LS}

Using the grain-size distributions of eroded sediments in runoff per minute during the 11 experimental tests as the objective functions, we fitted the four fractions $(\mathrm{C} 1-\mathrm{C} 4)$ using least squares to calculate the sand and loess compositions in the total eroded sediments from SS and LS under different simulated conditions. From this analysis, $\mathrm{C} 1+\mathrm{C} 2$ fraction was attributed to loess and $\mathrm{C} 3+\mathrm{C} 4$ fraction was attributed to sand. The mean compositional percentages of eroded sediments in all experimental tests are shown in Table 4.

As demonstrated in Table 4, regardless of the loess slopes with or without sand cover, the main eroded sediments were loess, with the percentage of $\mathrm{C} 1+\mathrm{C} 2$ fraction accounting for $>83 \%$ of the total eroded sediments on average. Furthermore, C2 fraction was the predominant and respectively accounted for $86 \%$ and $68 \%$ of the total eroded sediments from LS and SS, indicating that variations in the underlying surface conditions could influence the composition of eroded sediments. The sand percentage in the total eroded sediments varied with the sand cover patterns and rainfall intensities, with the percentage of $\mathrm{C} 3+\mathrm{C} 4$ fraction varying over a range from $9 \%$ to $25 \%$. Furthermore, C4 fraction was the predominant of eroded sand. Loess slopes with sand cover could influence the composition of eroded loess. Specifically, the mean ratio of C1 fraction to C2 fraction for LS was 0.162 , while it was 0.221 for SS. Hence, sand cover generally reduced the proportion of $\mathrm{C} 2$ erosion on loess slopes.

In this study, the splash-eroded sediments from LS was collected using splash erosion plates and then further analyzed. The results showed that the $\mathrm{d}_{50}$ of the splash-eroded sediments was 
$0.015 \mathrm{~mm}$. Grain-size distribution curves of the splash-eroded sediments and C2 fraction from LS are shown in Figure 3. Generally speaking, the two distribution curves were very similar in shape, but the sorting coefficient of the splash-eroded sediments (3.56) was higher than that of $\mathrm{C} 2$ fraction (3.07), indicating that the splash-eroded sediments were generated through further sorting of $\mathrm{C} 2$ from LS.

Table 4 Mean compositional percentage of eroded sediments in different experimental tests

\begin{tabular}{ccccc}
\hline Test No. & \multicolumn{2}{c}{ Compositional percentage (\%) } \\
\cline { 2 - 5 } LS-1.5 & C1 fraction & C2 fraction & C3 fraction & C4 fraction \\
LS-1.0 & 15 & 85 & 0 & 0 \\
LS-2.0 & 15 & 85 & 0 & 0 \\
Mean & 13 & 87 & 0 & 0 \\
SS-13.0-1.0-2.0 & 14 & 86 & 0 & 0 \\
SS-13.0-1.0-1.5 & 13 & 71 & 0 & 22 \\
SS-13.0-1.0-1.0 & 11 & 67 & 0 & 16 \\
SS-13.0-0.5-1.5 & 18 & 65 & 2 & 9 \\
SS-13.0-1.5-1.5 & 14 & 76 & 1 & 22 \\
SS-3.3-1.0-1.5 & 15 & 63 & 0 & 16 \\
SS-9.9-1.0-1.5 & 15 & 68 & 0 & 9 \\
SS-6.6-1.0-1.5 & 21 & 70 & 1 & 24 \\
Mean & 15 & 60 & 68 & 17 \\
\hline
\end{tabular}

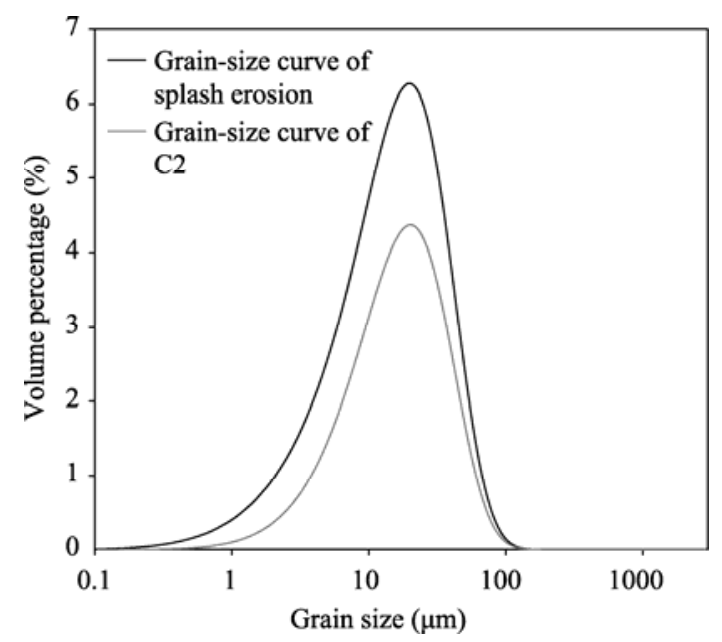

Fig. 3 Comparison of grain-size curves between splash-eroded sediments and C2 fraction from LS (uncovered loess slopes)

The intensity of splash erosion is related to the clay and silt percentage of soil (Saedi et al., 2016) and the soil aggregate properties (Abu-Hamdeh et al., 2006). In this study, the total clay and silt content in the sand layer was only 3.39\%; in contrast, the clay and silt content in the loess layer was $95.73 \%$ (Table 1). The lower clay and silt content in the sand layer relative to the underlying surface conditions led to the extremely low splash erosion intensity of SS in the initial of runoff and sediment generation. This suggests that sand cover on the loess slopes could change the rainfall-induced slope erosion process by reducing splash erosion.

\subsection{Variability characteristics of eroded sediments during runoff and sediment generation}

Although all experimental results demonstrated that eroded sediments were dominated by $\mathrm{C} 2$ fraction throughout the runoff and sediment generation, the compositional percentages of eroded 
sediments changed to various extents. The peak occurrence time, peak sand percentage and mean sand percentage of eroded sand during the first $5 \mathrm{~min}$ of runoff and sediment generation in different experimental tests are shown in Table 5. One noteworthy result is that it is possible to define three stages to describe the process of runoff and sediment generation. The first (early) stage occurred from the $1^{\text {st }}$ to the $5^{\text {th }}$ min of runoff and sediment generation at rainfall intensities of 1.0 and $1.5 \mathrm{~mm} / \mathrm{min}$. The second (intermediate) stage encompassed the period from the $6^{\text {th }}$ to the $20^{\text {th }}$ min of runoff and sediment generation at rainfall intensities of 1.0 and $1.5 \mathrm{~mm} / \mathrm{min}$, and from the $6^{\text {th }}$ to the $10^{\text {th }} \mathrm{min}$ of runoff and sediment generation at the rainfall intensity of $2 \mathrm{~mm} / \mathrm{min}$. The third (late) stage occurred from the $21^{\text {th }}$ to the $30^{\text {th }}$ min of runoff and sediment generation at rainfall intensities of 1.0 and $1.5 \mathrm{~mm} / \mathrm{min}$. It should be noted that the late stage at the rainfall intensity of $2 \mathrm{~mm} / \mathrm{min}$ occurred from the $11^{\text {th }}$ to the $15^{\text {th }} \mathrm{min}$ of runoff and sediment generation.

Table 5 Peak occurrence time, peak sand percentage, and mean sand percentage of eroded sand during the first 5 min of runoff and sediment generation in different experimental tests

\begin{tabular}{cccc}
\hline Test No. & $\begin{array}{c}\text { Peak occurrence } \\
\text { time (min) }\end{array}$ & $\begin{array}{c}\text { Peak percentage of C3+C4 } \\
\text { fraction }(\%)\end{array}$ & $\begin{array}{c}\text { Mean percentage of C3+C4 fraction in the first 5 } \\
\text { min }(\%)\end{array}$ \\
\hline LS-1.5 & 0 & 0 & 0 \\
LS-1.0 & 0 & 0 & 0 \\
LS-2.0 & 0 & 0 & 0 \\
SS-13.0-1.0-2.0 & 3 & 55 & 34 \\
SS-13.0-1.0-1.5 & 3 & 91 & 69 \\
SS-13.0-1.0-1.0 & 5 & 69 & 46 \\
SS-13.0-0.5-1.5 & 2 & 65 & 43 \\
SS-13.0-1.5-1.5 & 3 & 94 & 60 \\
SS-3.3-1.0-1.5 & 5,13 & 39 & 19 \\
SS-9.9-1.0-1.5 & 3 & 52 & 19 \\
SS-6.6-1.0-1.5 & 4 & 73 & 34
\end{tabular}

Note: Experimental test SS-3.3-1.0-1.5 produced two peaks of similar magnitude, occurring at the $5^{\text {th }}$ and $13^{\text {th }}$ min of runoff and sediment generation.

The results presented in Table 5 show that the peak sand $(\mathrm{C} 3+\mathrm{C} 4$ fraction) percentage in eroded sand was generally observed in the period of the $3^{\text {rd }}-5^{\text {th }}$ min, with the percentage value ranging from $39 \%$ to $94 \%$. Just one experiment (SS-3.3-1.0-1.5) produced two peaks of similar magnitude, occurring at the $5^{\text {th }}$ and $13^{\text {th }}$ min. This might because the amount and length of sand cover in this experiment were the smallest among the rainfall experiments, resulting in small and unstable peaks. The mean percentage of eroded sand from SS within the first 5 min of runoff and sediment generation ranged from $19 \%$ to $69 \%$ (Table 5), while the mean sand percentage of eroded sediments from SS in the whole process was 17\% (Table 4). These results show that sand erosion mainly occurs during the early stage of runoff and sediment generation.

To study the influence of rainfall intensity on the composition of eroded sediments, we compared the percentage variations of the main fraction (C2) in eroded sediments from SS and LS along with erosion time under three rainfall intensity levels $(1.0,1.5,2.0 \mathrm{~mm} / \mathrm{min})$, and the results are presented in Figure 4 and Table 6. For LS, the percentage of C2 in eroded sediments under the three rainfall intensity levels ranged from $81 \%$ to $89 \%$ (Fig. 4), and all coefficient of variation $\left(\mathrm{C}_{\mathrm{V}}\right)$ values for $\mathrm{C} 2$ over the whole rainfall event were relatively small (Table 6). These results indicate that the composition of eroded sediments from LS did not change significantly with rainfall duration and rainfall intensity. However, the composition of eroded sediments from SS changed markedly with runoff and sediment generation duration and rainfall intensity. The $\mathrm{C}_{V}$ values for $\mathrm{C} 2$ were the largest, and $\mathrm{C} 2$ changed most notably at the rainfall intensity of 1.5 $\mathrm{mm} / \mathrm{min}$, whereas the composition of eroded sediments changed only slightly at the highest rainfall intensity $(2 \mathrm{~mm} / \mathrm{min})$.

As shown in Figure 4, the percentage of $\mathrm{C} 2$ in eroded sediments from SS during the early stage of runoff and sediment generation varied dramatically at all rainfall intensity levels; however, it changed slightly during the late stage. By comparison, the percentage of $\mathrm{C} 2$ in eroded sediments 
from SS during the whole runoff and sediment generation changed slightly. These results mean that sand cover had influence on the erosion processes of loess slopes, and the changes mainly occurred in the early stage of runoff and sediment generation. As rainfall proceeded, stable erosion gullies formed, and the characteristics of eroded sediments from SS gradually became more similar to those from LS. In other words, the compositions of eroded sediments from SS and LS became more similar.
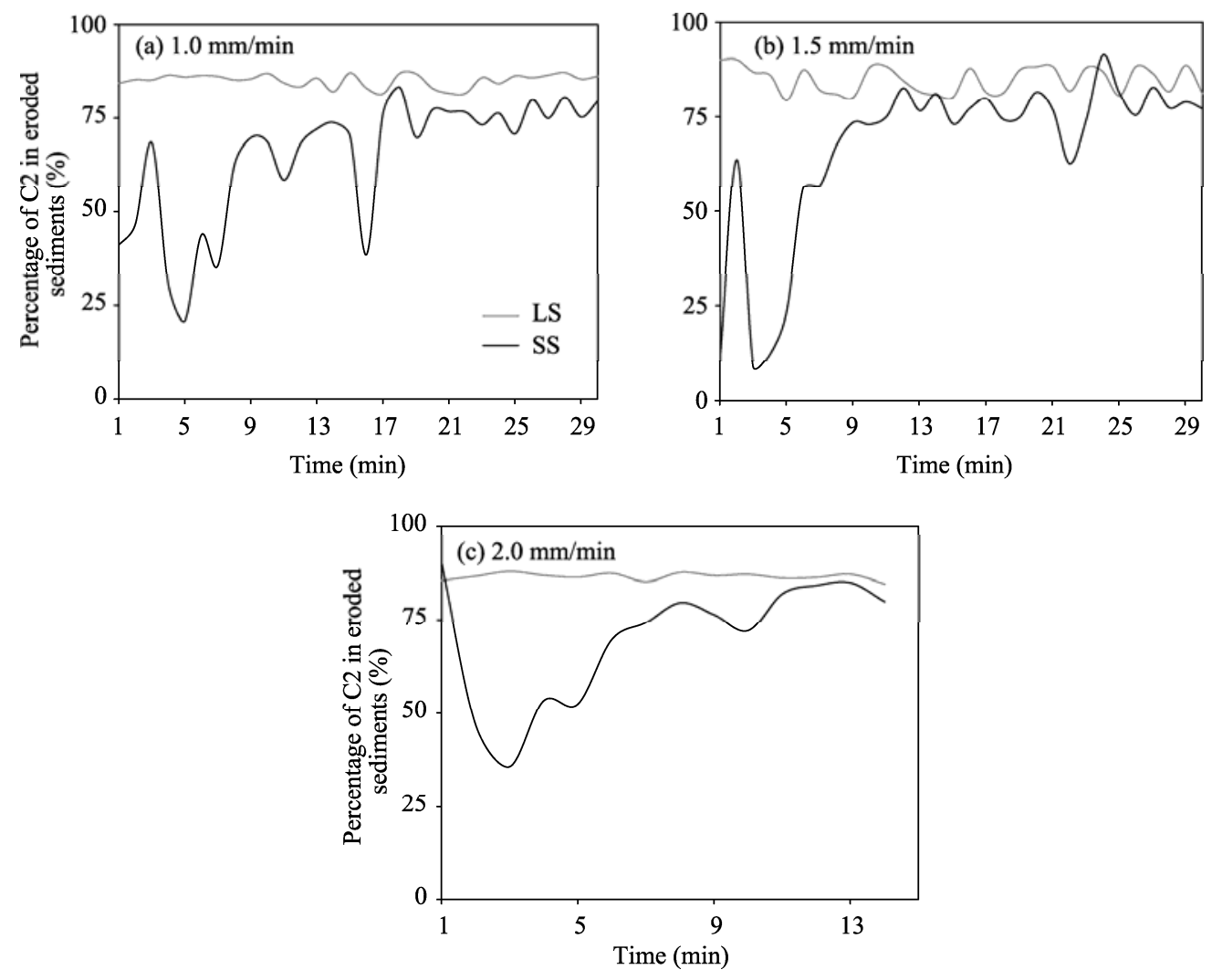

Fig. 4 Percentage variations of $\mathrm{C} 2$ in eroded sediments from SS (sand-covered loess slopes) and LS (uncovered loess slopes) along with erosion time under rainfall intensities of (a) $1.0 \mathrm{~mm} / \mathrm{min}$, (b) $1.5 \mathrm{~mm} / \mathrm{min}$, and (c) 2.0 $\mathrm{mm} / \mathrm{min}$

Table 6 Coefficient of variation $\left(\mathrm{C}_{\mathrm{V}}\right)$ values for $\mathrm{C} 2$ in eroded sediments from SS and LS during different stages of runoff and sediment generation in the selected experimental tests

\begin{tabular}{ccccccc}
\hline Runoff and sediment generation & LS-1.0 & SS-13.0-1.0-1.0 & LS-1.5 & SS-13.0-1.0-1.5 & LS-2.0 & SS-13.0-1.0-2.0 \\
\hline Whole duration & 0.02 & 0.26 & 0.04 & 0.33 & 0.01 & 0.23 \\
Early stage & 0.01 & 0.43 & 0.05 & 0.95 & 0.01 & 0.37 \\
Intermediate stage & 0.02 & 0.22 & 0.04 & 0.11 & 0.01 & 0.05 \\
Late stage & 0.02 & 0.04 & 0.04 & 0.09 & 0.01 & 0.03 \\
\hline
\end{tabular}

\section{Discussion}

\subsection{Influences of sand cover amount on erosion processes of loess slopes}

Changes in ambient conditions can influence the erosion processes of slopes (Huang et al., 2016). The influences of rainfall intensity and sand cover pattern on erosion processes of slopes can be reflected by the changes in runoff yield and amount of eroded sediments (Rodríguez-López et al., 2012). In this study, the amount of sand cover and corresponding total amount of eroded sediments in different experimental tests are shown in Table 7. These data could be used to further explore the influences of rainfall intensity and sand cover pattern on erosion processes of loess slopes. 
Table 7 Amounts of sand cover and total eroded sediments recorded in different experimental tests

\begin{tabular}{crrr}
\hline Test No. & $\begin{array}{c}\text { Amount of sand cover } \\
(\mathrm{kg})\end{array}$ & $\begin{array}{c}\text { Total amount of eroded sediments }(\mathrm{kg}) \\
\text { LS-1.0 }\end{array} \quad 0.00$ & $\begin{array}{c}\text { Increment of eroded sediments from } \\
\text { SS relative to from LS (kg) }\end{array}$ \\
SS-13.0-1.0-1.0 & 344.50 & 275.90 & 263.99 \\
LS-1.5 & 0.00 & 38.69 & 474.70 \\
SS-13.0-1.0-1.5 & 344.50 & 513.39 & 547.14 \\
SS-13.0-0.5-1.5 & 172.25 & 585.83 & 817.07 \\
SS-13.0-1.5-1.5 & 516.75 & 855.76 & 56.10 \\
SS-3.3-1.0-1.5 & 87.45 & 94.79 & 247.02 \\
SS-9.9-1.0-1.5 & 262.35 & 285.71 & 274.41 \\
SS-6.6-1.0-1.5 & 172.25 & 313.10 & 362.74 \\
LS-2.0 & 0.00 & 214.09 & 5 \\
SS-13.0-1.0-2.0 & 344.50 & 540.83 & \\
\hline
\end{tabular}

Note: The increment of eroded sediments from SS relative to from LS was calculated by the difference between the total amount of eroded sediments from SS and the total amount of eroded sediments from LS at the same rainfall intensity.

Given the same rainfall intensity, the amounts of eroded sediments from SS were larger than those from LS. The increments of eroded sediments for SS-13.0-1.0-1.5, SS-13.0-0.5-1.5, SS-13.0-1.5-1.5, SS-6.6-1.0-1.5, and SS-13.0-1.0-2.0 were all larger than the corresponding amounts of sand cover, demonstrating that sand cover not only provided additional eroded sediments for loess slopes but also exacerbated the erosion of loess slopes to a certain extent. There are also some other studies demonstrated that the sand layer on the loess slopes could significantly influence the processes and mechanisms of runoff and sediment generation (Xu et al., 2015; Zhang et al., 2017a). The sand cover on loess slopes may destroy the stability of the water flow, further aggravating soil erosion of loess slopes (Zhang et al., 2017b).

To analyze the increments of eroded sediments from SS relative to from LS, we calculated the amount of sand cover in eroded sediments per minute by multiplied each sand cover proportion in eroded sediments by the corresponding amount of eroded sediments per minute. Variations in the amounts of $\mathrm{C} 1+\mathrm{C} 2$ and $\mathrm{C} 3+\mathrm{C} 4$ in the early and late stages of runoff and sediment generation under different amounts of sand cover are shown in Figure 5. The amount of $\mathrm{C} 1+\mathrm{C} 2$ represented the mass of eroded loess, and the amount of $\mathrm{C} 3+\mathrm{C} 4$ represented the mass of eroded sand.
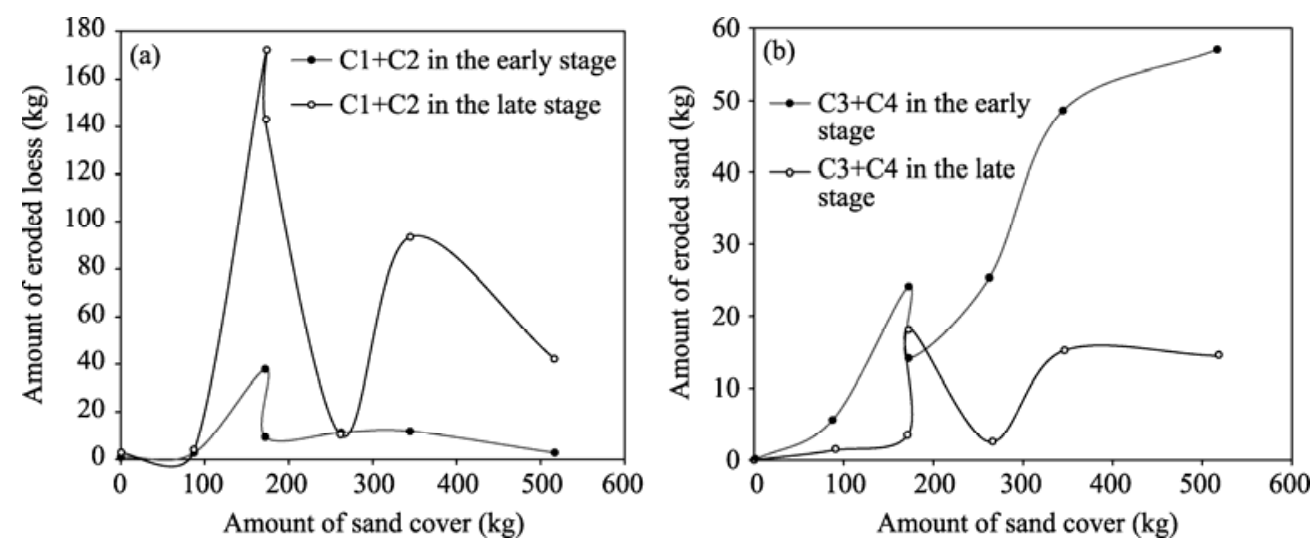

Fig. 5 Variations in amounts of eroded loess (a) and eroded sand (b) in the early and late stages of runoff and sediment generation under different amounts of sand cover

From Figure 5 it can be concluded that the amount of eroded loess $(\mathrm{C} 1+\mathrm{C} 2)$ in the early stage of runoff and sediment generation was always smaller than that in the late stage, especially for the $172.25 \mathrm{~kg}$ amount of sand cover. By contrast, the amount of eroded sand $(\mathrm{C} 3+\mathrm{C} 4)$ in the early stage was always larger than that in the late stage, with an exception of the $172.25 \mathrm{~kg}$ amount of sand cover. In the early stage, the amount of eroded sand $(\mathrm{C} 3+\mathrm{C} 4)$ in the SS-13.0-0.5-1.5 case 
(172.25 kg amount of sand cover) was larger than that in the SS-6.6-1.0-1.5 case $(172.25 \mathrm{~kg}$ amount of sand cover); while in the late stage, the amount of eroded sand $(\mathrm{C} 3+\mathrm{C} 4)$ was larger in the SS-6.6-1.0-1.5 case than in the SS-13.0-0.5-1.5 case. These results indicate that sand cover pattern has considerable influence on erosion processes of loess slopes.

\subsection{Influences of sand cover pattern on erosion processes of loess slopes}

In this study, we conducted paired comparison analyses for experimental tests of SS-13.0-1.0-1.5, SS-13.0-0.5-1.5, SS-6.6-1.0-1.5, and LS-1.5 under the rainfall intensity of $1.5 \mathrm{~mm} / \mathrm{min}$ to study the influences of sand cover pattern on erosion processes of loess slopes (Table 8). It should be noted that tests SS-13.0-1.0-1.5 and SS-13.0-0.5-1.5 had the same sand cover length but different sand cover amounts and thicknesses, while tests SS-13.0-0.5-1.5 and SS-6.6-1.0-1.5 had the same amount of sand cover but different sand cover patterns (thickness and length).

Table 8 Amounts of sand cover, total eroded sediments, eroded sand and eroded loess as well as runoff yield in the selected four experimental tests

\begin{tabular}{cccccc}
\hline Test No. & $\begin{array}{c}\text { Amount of sand } \\
\text { cover }(\mathrm{kg})\end{array}$ & $\begin{array}{c}\text { Amount of total eroded } \\
\text { sediments }(\mathrm{kg})\end{array}$ & $\begin{array}{c}\text { Amount of total } \\
\text { eroded sand }(\mathrm{kg})\end{array}$ & $\begin{array}{c}\text { Amount of total } \\
\text { eroded loess }(\mathrm{kg})\end{array}$ & $\begin{array}{c}\text { Runoff yield } \\
\left(\mathrm{m}^{3}\right)\end{array}$ \\
\hline SS-13.0-1.0-1.5 & 344.50 & 513.39 & 110.17 & 403.22 & 455.47 \\
SS-13.0-0.5-1.5 & 172.25 & 585.83 & 44.69 & 541.14 & 501.99 \\
SS-6.6-1.0-1.5 & 172.25 & 313.10 & 68.93 & 244.17 & 393.49 \\
LS-1.5 & 0.00 & 38.69 & 0.00 & 38.72 & 347.12 \\
\hline
\end{tabular}

The results from Table 8 show that tests SS-13.0-1.0-1.5 and SS-13.0-0.5-1.5 with the same sand cover length but different sand cover amounts and thicknesses exhibited similar amount of total eroded sediments and runoff yield, with the values being slightly higher for test SS-13.0-0.5-1.5 than for test SS-13.0-1.0-1.5 (increments of $72.44 \mathrm{~kg}$ and $46.52 \mathrm{~m}^{3}$, respectively). However, for tests SS-13.0-0.5-1.5 and SS-6.6-1.0-1.5 with the same amount of sand cover but different sand cover patterns, the amount of eroded sediments and runoff yield were largely higher for test SS-13.0-0.5-1.5 than for test SS-6.6-1.0-1.5 (increments of $272.73 \mathrm{~kg}$ and $108.5 \mathrm{~m}^{3}$, respectively). This result indicates that the influences of sand cover pattern on the amount of total eroded sediments and runoff yield were much larger than those of sand cover amount. Furthermore, the amount of eroded sand was higher for test SS-13.0-1.0-1.5 than for test SS-13.0-0.5-1.5 (increment of $65.48 \mathrm{~kg}$ ), while the amount of eroded loess was higher for test SS-13.0-0.5-1.5 than for test SS-13.0-1.0-1.5 (increment of $137.92 \mathrm{~kg}$ ). This indicates that given the same length of sand cover, the thicker sand layer could increase sand erosion, while the thinner sand layer could aggravated loess erosion.

The amounts of eroded loess and eroded sand along with time period during the erosion processes in the experimental tests of SS-13.0-1.0-1.5, SS-13.0-0.5-1.5 and SS-6.6-1.0-1.5 are shown in Figure 6. The results show large differences in the amount of eroded sand among the three experimental tests in the early stage of runoff and sediment generation. And, the amount of eroded sand decreased rapidly and tended to become stable during the intermediate and late stages of runoff and sediment generation. These results are likely related to the differences in infiltration rates between sand and loess layers (Janeau et al., 2003) resulted from discrepancies of relative porosities (Van Dijk and Bruijnzeel, 2004). Previous research has shown that the presence of sand cover on slopes can extend the time period from rainfall to runoff and sediment generation (4-14 times) and increase the infiltration rate by $0.2-2.0$ times ( $\mathrm{Xu}$ et al., 2015). The infiltration rate of sand layer was greater than that of loess layer, and hence the infiltration was considered as laminar flow, which is similar to interflow and may have formed at the sand-loess interface (Eastham et al., 2000; Hardie et al., 2013). This interflow initiates surface runoff when the water table depth within the sand layer reaches a critical value and a peak erosion rate is subsequently attained (Iida, 2004; Fox and Wilson, 2010). Therefore, the sand layer was transported in the form of a bed load instead of a suspended load in the early stage of runoff and sediment generation, and the sand erosion showed an obvious peak in the early stage of runoff and sediment generation (Fig. 6b). 

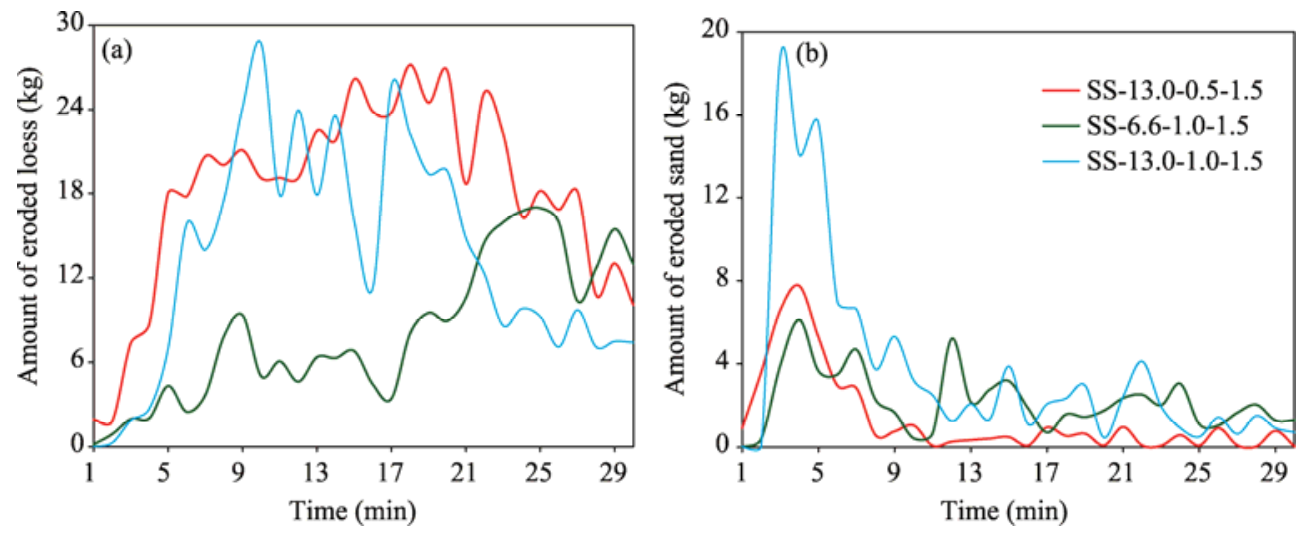

Fig. 6 Amounts of eroded loess (a) and eroded sand (b) along with time period during runoff and sediment generation in the experimental tests SS-13.0-0.5-1.5, SS-13.0-1.0-1.5 and SS-6.6-1.0-1.5

By comparing the amounts of eroded loess and eroded sand between experimental tests SS-13.0-1.0-1.5 and SS-6.6-1.0-1.5, we found that both the amounts of eroded loess and eroded sand were higher for test SS-6.6-1.0-1.5 (one-half slope) than for test SS-13.0-1.0-1.5 (whole slope) during the late stage of runoff and sediment generation. Indeed, the time period before runoff and sediment generation on SS was much longer than that on LS under the same rainfall intensity (Xu et al., 2015). The loess surface of slopes covered by sand with one-half of the total length (SS-6.6-1.0-1.5) generated runoff and sediments firstly, but the generation was intercepted by the remaining sand surface (one-half slope) and then retained in the sand cover layer, leading to a centralized runoff and sediment release after a given time period. This inference was confirmed by the runoff coefficients shown in Figure 7.

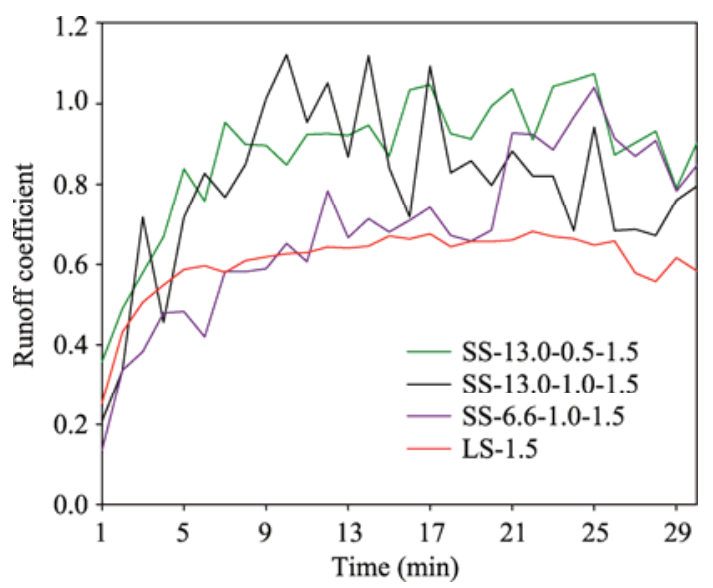

Fig. 7 Runoff coefficients along with time period for experimental tests SS-13.0-0.5-1.5, SS-13.0-1.0-1.5, SS-6.6-1.0-1.5, and LS-1.5

For tests SS-13.0-1.0-1.5 and SS-13.0-0.5-1.5, runoff coefficient being higher than 1.0 occurred in the intermediate stage of runoff and sediment generation. For test SS-6.6-1.0-1.5, the runoff coefficient increased along with time period and there was an abrupt value $(>1.0)$ in the late stage of runoff and sediment generation. Moreover, the runoff coefficient was always lower than 1.0 for test LS-1.5. Fox and Wilson (2010) indicated that sand layer coverage changes the generation mode of runoff and sediments. Some other studies also demonstrated that the runoff coefficient can be greater than 1.0 for sand-covered slopes during runoff and sediment generation (Martínez-Murillo et al., 2013; Zhao et al., 2013; Zhang et al., 2017a). With increasing amount of sand cover, the time period before runoff and sediment generation increased, demonstrating that sand-covered areas at low elevations can intercept runoff and sediments generated from slopes 
and that sand layers can provide storage and release of runoff and eroded sediments $(\mathrm{Ng}$ et al., 2015). The storage and release processes could be the main reasons why SS generated a large amount of eroded sediments.

\section{Conclusions}

The eroded sediments from SS during runoff and sediment generation is dominated by loess, which accounts for $83 \%$ of the total eroded sediments on average. The sand cover on loess slopes transform silt erosion to sand erosion by reducing splash erosion and changing the rainfall-induced slope erosion process. The peak sand percentage in eroded sand generally occurs in the early stage of runoff and sediment generation, and the proportion of eroded sand from SS in the early stage is always higher than that in the late stage.

Sand covered on loess slopes not only adds additional eroded sediments but also increases the amount of eroded loess. The influence of sand cover pattern on runoff yield and the amount of eroded sediments is larger than that of sand cover amount. In contrast, given the same length of sand cover, a thinner sand layer slightly reduces the sand erosion but significantly aggravates the erosion of background sediments. This will lead to a significant increase in the amount of eroded sediments from aeolian-fluvial interplay erosion regions to river channels. It should be noted that this research mainly focused on the influences of sand cover on erosion processes of loess slopes. On the basis of this study, the critical condition of the peak eroded sediments of SS and the relationship between erosion energy and eroded sediments can be further studied in the future, which are crucial for erosion prediction.

\section{Acknowledgements}

This research was supported by the National Key Research and Development Program of China (2016YFC0402404, 2016YFC0402407), the National Natural Science Foundation of China (L1624052, 41330858, 41471226, and 51509203), and the Dr. Innovation Fund of Xi' an University of Technology (310-252071505).

\section{References}

Abrahams A D, Li G, Krishnan C, et al. 2001. A sediment transport equation for interrill overland flow on rough surfaces. Earth Surface Processes and Landforms, 26(13): 1443-1459.

Abu-Hamdeh N H, Abo-Qudais S A, Othman A M. 2006. Effect of soil aggregate size on infiltration and erosion characteristics. European Journal of Soil Science, 57(5): 609-616.

Banham S G, Mountney N P. 2014. Climatic versus halokinetic control on sedimentation in a dryland fluvial succession. Sedimentology, 61(2): 570-608.

Eastham J, Gregory P J, Williamson D R. 2000. A spatial analysis of lateral and vertical fluxes of water associated with a perched watertable in a duplex soil. Australian Journal of Soil Research, 38(4): 879-890.

Foster G R, Huggins L F, Meyer L D. 1984. A laboratory study of rill hydraulics: I. Velocity relationships. Transactions of the ASAE, 27(3): 790-796.

Fox G A, Wilson G V. 2010. The role of subsurface flow in hillslope and stream bank erosion: a review. Soil Science Society of America Journal, 74(3): 717-733.

Garcia-Estringana P, Alonso-Blázquez N, Marques M J, et al. 2010. Direct and indirect effects of Mediterranean vegetation on runoff and soil loss. European Journal of Soil Science, 61(2): 174-185.

Hardie M, Doyle R, Cotching W, et al. 2013. Hydropedology and preferential flow in the tasmanian texture-contrast soils. Vadose Zone Journal, 12(4), doi: 10.2136/vzj2013.03.0051.

Huang X, Shi Z H, Zhu H D, et al. 2016. Soil moisture dynamics within soil profiles and associated environmental controls. CATENA, 136: 189-196.

Iida T. 2004. Theoretical research on the relationship between return period of rainfall and shallow landslides. Hydrological Processes, 18(4): 739-756.

Janeau J L, Bricquet J P, Planchon O, et al. 2003. Soil crusting and infiltration on steep slopes in northern Thailand. European Journal of Soil Science, 54(3): 543-554.

Kocurek G. 1998. Aeolian system response to external forcing factors—a sequence stratigraphic view of the Saharan region. In: Alsharhan A S, Glennie K W, Whittle G L, et al. Quaternary Deserts and Climatic Change. Dordrecht: Balkema, 327-337. 
Li J C, Liu H X, Su Z Z, et al. 2015. Changes in wind activity from 1957 to 2011 and their possible influence on aeolian desertification in northern China. Journal of Arid Land, 7(6): 755-764.

Liu B, Jin H L, Sun Z, et al. 2016. Geochemical weathering of Aeolian sand and its palaeoclimatic implications in the Mu Us Desert, northern China, since the Late Holocene. Journal of Arid Land, 8(5): 647-659.

Mandal U K, Rao K V, Mishra P K, et al. 2005. Soil infiltration, runoff and sediment yield from a shallow soil with varied stone cover and intensity of rain. European Journal of Soil Science, 56(4): 435-443.

Martínez-Murillo J F, Nadal-Romero E, Regüés D, et al. 2013. Soil erosion and hydrology of the western Mediterranean badlands throughout rainfall simulation experiments: a review. CATENA, 106: 101-112.

Ng C W W, Liu J, Chen R, et al. 2015. Physical and numerical modeling of an inclined three-layer (silt/gravelly sand/clay) capillary barrier cover system under extreme rainfall. Waste Management, 38: 210-221.

Rodríguez-López J P, Liesa C L, Van Dam J, et al. 2012. Aeolian construction and alluvial dismantling of a fault-bounded intracontinental aeolian dune field (Teruel Basin, Spain); a continental perspective on Late Pliocene climate change and variability. Sedimentology, 59(5): 1536-1567.

Saedi T, Shorafa M, Gorji M. et al. 2016. Indirect and direct effects of soil properties on soil splash erosion rate in calcareous soils of the central Zagross, Iran: A laboratory study. Geoderma, 271: 1-9.

Shen H O, Zheng F L, Wen L L, et al. 2016. Impacts of rainfall intensity and slope gradient on rill erosion processes at loessial hillslope. Soil and Tillage Research, 155: 429-436.

Shi Z H, Fang N F, Wu F Z, et al. 2012. Soil erosion processes and sediment sorting associated with transport mechanisms on steep slopes. Journal of Hydrology, 454: 123-130.

Sun D H, An Z S, Su R X, et al. 2001. Mathematical approach to sedimentary component partitioning of polymodal sediments and its applications. Progress in Natural Science, 11(5): 374-382.

Sun D H, Bloemendal J, Rea D K, et al. 2002. Grain-size distribution function of polymodal sediments in hydraulic and aeolian environments, and numerical partitioning of the sedimentary components. Sedimentary Geology, 152(3-4): $263-277$.

Sun J M. 2002. Provenance of loess material and formation of loess deposits on the Chinese Loess Plateau. Earth and Planetary Science Letters, 203(3-4): 845-859.

Ta W Q, Wang H B, Jia X P. 2014. Aeolian process-induced hyper-concentrated flow in a desert watershed. Journal of Hydrology, 511: 220-228.

Turowski J M, Rickenmann D, Dadson S J. 2010. The partitioning of the total sediment load of a river into suspended load and bedload: a review of empirical data. Sedimentology, 57(4): 1126-1146.

Van Dijk A I J M, Bruijnzeel L A. 2004. Runoff and soil loss from bench terraces. 1. An event-based model of rainfall infiltration and surface runoff. European Journal of Soil Science, 55(2): 299-316.

Wang L, Shi Z H. 2015. Size selectivity of eroded sediment associated with soil texture on steep slopes. Soil Science Society of America Journal, 79(3): 917-929.

Weltje G J, Prins M A, 2007. Genetically meaningful decomposition of grain-size distributions. Sedimentary Geology, 202(3): 409-424.

Xiao J L, Fan J W, Zhou L, et al. 2013. A model for linking grain-size component to lake level status of a modern clastic lake. Journal of Asian Earth Sciences, 69: 149-158.

Xu G C, Tang S S, Lu K X, et al. 2015. Runoff and sediment yield under simulated rainfall on sand-covered slopes in a region subject to wind-water erosion. Environmental Earth Sciences, 74(3): 2523-2530.

Xu J X. 2014. The influence of dilution on downstream channel sedimentation in large rivers: the Yellow River, China. Earth Surface Processes and Landforms, 39(4): 450-462.

Yao H F, Shi C X, Shao W W, et al. 2016. Changes and influencing factors of the sediment load in the Xiliugou basin of the upper Yellow River, China. CATENA, 142: 1-10.

Zhang F B, Bai Y J, Xie L Y, et al. 2017a. Runoff and soil loss characteristics on loess slopes covered with aeolian sand layers of different thicknesses under simulated rainfall. Journal of Hydrology, 549: 244-251.

Zhang F B, Yang M Y, Li B B, et al. 2017b. Effects of slope gradient on hydro-erosional processes on an aeolian sand-covered loess slope under simulated rainfall. Journal of Hydrology, 553: 447-456.

Zhang K C, Zhang W M, Tan L H, et al. 2015. Effects of gravel mulch on aeolian transport: a field wind tunnel simulation. Journal of Arid Land, 7(3): 296-303.

Zhang X, Li Z B, Li P, et al. 2015. A model to study the grain size components of the sediment deposited in aeolian-fluvial interplay erosion watershed. Sedimentary Geology, 330: 132-140.

Zhao X N, Wu P T, Chen X L, et al. 2013. Runoff and sediment yield under simulated rainfall on hillslopes in the Loess Plateau of China. Soil Research, 51(1): 50-58.

Zheng F L, He X B, Gao X T, et al. 2005. Effects of erosion patterns on nutrient loss following deforestation on the Loess Plateau of China. Agriculture, Ecosystems \& Environment, 108(1): 85-97. 